\title{
The Early History of Gold Plating
}

\section{A TANGLED TALE OF DISPUTED PRIORITIES}

\author{
L. B. Hunt \\ Johnson Matthey \& Co Limited, London \\ "The gilding of metals is, of all the processes whose object is to \\ obtain an adhering deposit, the one which has exercised in the greatest \\ degree the sagacity of inventors"
}

Professor Auguste de la Rive, Geneya, 1840

Many of the scientfic discoveries and technical developments that were so characteristic of the nineteenth century rapidly became the subject of controversy and of heated arguments about priorities. Of all these, none was probably more sorely beset by polemics and acrimonious debate-or for a longer period of time-than the birth of a commercially satisfactory process for the electrodeposition of gold (and of silver with which it was naturally associated) on to base metals. It must also come close to world record standards for the number and the diversity of the scientists and dilettante whose contributions eventually led to success; not only were there numerous professors and medical men involved, but a curious collection that included an unsuccessful French opera composer, a leading English astronomer, a St Petersburg dentist, the son-in-law of the Tsar of Russia, one of the famous Siemens family and the founder of the University of Birmingham. But it was an exceptionally far-sighted and persistent industrialist-George Richards Elkington-who finally transformed laboratory experiments into a commercial process.

To put the early history of gold plating into perspective, and to follow the trail that eventually led to success, one has first of all to consider the development of electrodeposition as a whole, and in fact of the battery itself; the basic origin of all this was of course the discovery by Alessandro Volta of his famous pile.

In order to counter the explanation put forward by Luigi Galvani that animal tissue itself possessed a special electrical property, Volta had begun experimenting on the effects of two dissimilar metallic elements in contact, and by 1796 he had constructed a column of electric generating elements consisting of silver and zinc plates in contact, each pair separated by a moist pad. For another four years he continued to make improvements in the pile, and finally, in the March of 1800 , he wrote a long letter to the then
President of the Royal Society, Sir Joseph Banks. Because the letter would have to pass through France, then engaged in the Napoleonic wars with England, Volta sent only the first part of the letter, the second part following three months later, so that it was not read to the Royal Society until the end of June of that year. None the less, the receipt of the earlier part of the letter was enough to cause considerable excitement among the scientists of the period, since it now made available for the first time a low voltage continuous current as opposed to the high voltage discharges, lasting only a fraction of a second, from the static electrical machines.

\section{Experiments with Volta's Pile}

Sir Joseph Banks had quickly conveyed to some of his friends in the Royal Society the contents of the first part of Volta's letter, and among these were William Nicholson (a man who combined the professions of scientist, mathematician, patent expert and water engineer with the editing and publishing of Nicholson's Fournal of Natural Philosophy), Sir Anthony Carlisle, the chief surgeon of Westminster Hospital, and William Cruickshank.

They immediately set about constructing Volta's piles for themselves, and, as is well known, Nicholson and Carlisle first observed, in May 1800, the decomposition of water by the electric current. But of particular interest in the present context is the latter part of Nicholson's paper, published in the following July. After describing the evolution and collection of hydrogen and oxygen evolved at the ends of brass wires immersed in water, using a pile consisting of 36 half-crowns and the same number of pieces of zinc and pasteboard soaked in salt water, Nicholson goes on:

"As the ample field of physiological research to which Mr Carlisle's attention is directed, and the multiplicity of my own avocations, rendered it less convenient for us to pursue our inquiries together, I constructed an apparatus for my own use. ... On account of the length 


\section{The First Recorded Experiment in Gold Plating}

In 1803 Professor Luigi Brugnatelli, a close friend and colleague of Volta's at the University of Pavia, wrote to his correspondent Professor Van Mons of Brussels describing how he had "recently gilt in a perfect manner two large silver medals, by bringing them into communication, by means of a steel wire, with the negative pole of a Voltaic pile, and keeping them, one after the other, immersed in ammoniuret of gold newly made and well saturated".

Brugnatelli later gave details of his electrolyte: "To one part of the saturated solution of gold in nitromuriatic acid, add six parts of solution of ammonia, by which the solution is decomposed and oxide of gold is precipitated, and a portion is set free, forming ammoniuret of gold".
Extruit d'une lettre de BrugNATRzFi:

\section{Galvanisme.}

Yolta travaille toujours sur l'électricité. II a dernierrement construit différentes piles come posées de seules substances sảlines de différente nature, avec les solutions desquels il imprégnait des disques d'os. Lorsqu'il aura terminés son travail, je vous le communiquerai.

J'ai dernièrement doré, d'nne manière parfaite, deux grandes módailles d'argent ẹn les faisant communiquer, d̀ l'aide d'un fil d'acier, avec le pole négatif d'une pile de Volta et en les tenant, l'ane après l'autre, plongées dans de l'ammoniure d'or nopuvellement faite et bien saturée. of this communication, I shall at present forbear to enter into any considerations of theory, but shall conclude with a concise mention of the effects of a pile of one hundred half-crowns, and a chemical incident, which appears to be the most remarkable of those which I have yet observed."

Copper wires were used for the circuit in this experiment, with very dilute hydrochloric acid. When the wires were moved to within a third of an inch of each other

"the minus wire gave out some hydrogen during an hour, while the plus wire was corroded, and exhibited no

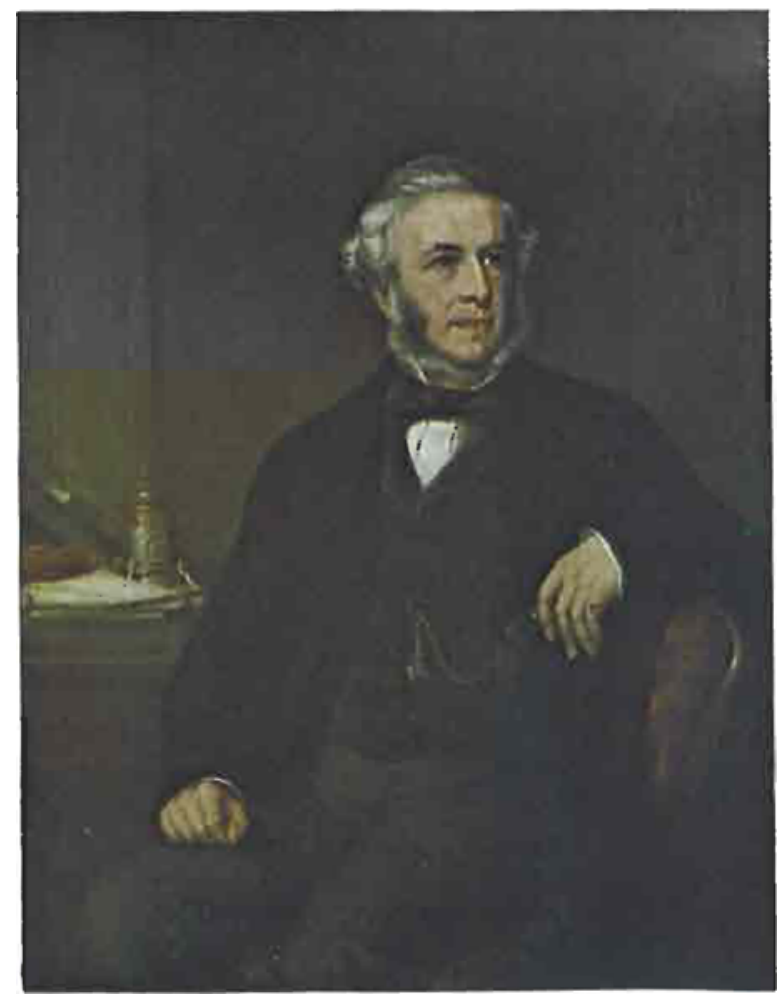

oxide; but a deposition of copper was formed round the minus, or lower wire, which began at its lower end ... and that deposition at the end of four hours formed a ramified metallic vegetation, nine or ten times the bulk of the wire it surrounded."

The paper immediately following Nicholson's contribution in his own journal came from William Cruickshank-not William Cumberland Cruickshank, who was an anatomist and surgeon and who is often credited with this paper in the literature, but $\mathrm{Mr}$ William Cruickshank who was Chemist to the Ordnance and lecturer in chemistry at the Royal Military Academy at Woolwich. He too had collected hydrogen and oxygen by the electrolysis of water, but he also went on to observe the rudimentary phenomenon of electrodeposition.

"The tube was filled with a solution of acetate of lead, to which an excess of acid was added to counteract the effects of the alkali. When the communication was made in the usual way, no gas could be perceived, but after a minute or two, some fine metallic crystals were perceived at the extremity of the wire. These soon increased, and assumed the form of a feather. The lead thus precipitated

\section{George Richards Elkington 1800-1865}

On March 25th, 1840, George Richards Elkington and his cousin Henry Elkington filed a patent for gold and silver plating. The final specification of September 25th incorporated the use of cyanide baths proposed by Joln Wright, the Birmingham surgeon, and from this development stemmel the whole commercial success of the proeess, although the work of many others had led up to it and many more were to make their contribution. Elkington's major role lay in his gathering of all the threals together and in taking the first practical steps to put them into industrial use. From a portrait by Samuel West in the City Museum and Art Gallery,
Birmingham) 
was perfectly in its metallic state, and very brilliant. . . . A solution of the sulphate of copper was next employed, and with the same result, the copper being precipitated in its metallic form. . . The most beautiful precipitate however, was that of silver from its solution in the nitrous acid. In this case, the metal shot into fine needle-like crystals articulated or joined to each other."

Closely similar experiments were made in the following year, 1801, in Germany and in France. The court apothecary at Hanover, J. L. W. Gruner, obtained growths of silver from silver nitrate, while K. W. Boeckmann, a lecturer in physics at Karlsruhe, deposited copper, silver and tin. Charles Bernard Désormes of the Ecole Polytechnique (later to become both a chemical manufacturer and a leading politician in the French troubles of 1848) also deposited silver crystals from solutions of silver nitrate. All these early researches, following so quickly upon Volta's announcement, led only of course to the formation of feathery or dendritic deposits, and the idea of depositing a uniform layer of metal had yet to be conceived.

However, in the same year William Hyde Wollaston, who was seeking to establish the identity of "common electricity", obtained from the static machines, with voltaic electricity, did observe, in the Transactions of the Royal Society, that if silver wires were immersed in a solution of copper sulphate and a discharge was passed between them

"the negative conductor had a precipitate formed on its surface, which, upon being burnished, was evidently copper".

\section{The Brugnatelli Letter}

But for the first reference ever made to gold plating, and apparently to the deposition of a reasonably even film of metal, we have to go back to the University of Pavia, where Volta was Professor of Natural Philosophy. His colleague and friend in the chair of chemistry was Luigi Brugnatelli, almost as distinguished a scientist as Volta. Brugnatelli was a prolific correspondent with his fellow scientists throughout Europe, and also the editor of Annali di Chimica, published in Pavia during the years 1790 to 1805 . In a letter to his friend Professor Jean Baptiste Van Mons of Brussels, the editor of a similar journal, Annales de Chimie de Van Mons, published in Paris, Brugnatelli describes the gold plating of two large silver medals from a solution of ammoniuret of gold. The extract from this letter, published by Van Mons in 1803, is reproduced here. (It has often been quoted in its English translation published in the Philosophical Magazine of 1805, but never hitherto has the original been located.)

Curiously this announcement by Brugnatelli appears to have escaped notice for many years, doubtless largely due to the state of war that persisted until 1815 , and it was not even mentioned by the dis- tinguished scientists commissioned by Napoleon to report on scientific progress after the French Revolution. In fact, George Shaw of Birmingham, writing in 1842 in his book $A$ Manual of Electrometallurgy, says

"From Brugnatelli to 1830 no experiments were published on the applications of electricity to the deposition of metals for the purpose of art."

We shall never know, of course, anything of the quality of Brugnatelli's gold plating. We can only accept that he was a scientist of repute and integrity, and that his report was probably soundly based. But no real progress in electroplating could be made with Volta's pile or with the many versions of a battery that were constructed on the same basis by scientists all over Europe in the years immediately following his discovery. Over thirty years had to go by before there was made available, as will be mentioned later, a reliable primary cell that did not deteriorate rapidly from local action or polarisation or both.

\section{The Davys and Faraday}

The great Sir Humphry Davy, working at the Royal Institution, delivered the first of his Bakerian lectures to the Royal Society in 1806 on "Some Chemical Agencies of Electricity", and while he mentioned brieffy that

\begin{abstract}
"when metallic solutions were employed, metallic crystals or depositions were formed, as is common in GALVANIC experiments, on the negative wire. ... In a case in which solution of nitrate of silver was used on the positive side, and distilled water on the negative, silver appeared on the whole of the transmitting amianthus, ${ }^{\star}$ so as to cover it with a thin metallic film"
\end{abstract}

his mind was dwelling upon quite different aspects of electrochemistry, particularly the separation of hydrogen and the alkalies at the negative surface and of oxygen and acids at the positive surface, and of course he went on to discover the elements sodium and potassium by this means, as reported in his second Bakerian lecture the following year, 1807 .

In fact it seems that the great excitement occasioned by Volta's discovery was now beginning to die down, and in some scientific circles it was even felt that practically everything had been discovered that might usefully be expected from the pile! The following twenty years and more were therefore something of a fallow period in electrochemistry, but in 1830 there occurs a rather tantalising reference to electroplating on the part of Edmund Davy, Sir Humphry's young cousin who was then Professor to the Royal Dublin Society. Davy proposed that electrochemical methods could be used to detect the presence of minute

* A type of asbestos, moistened with water, used by Davy to complet his circuits. The idea was first conceived by Wollaston. 


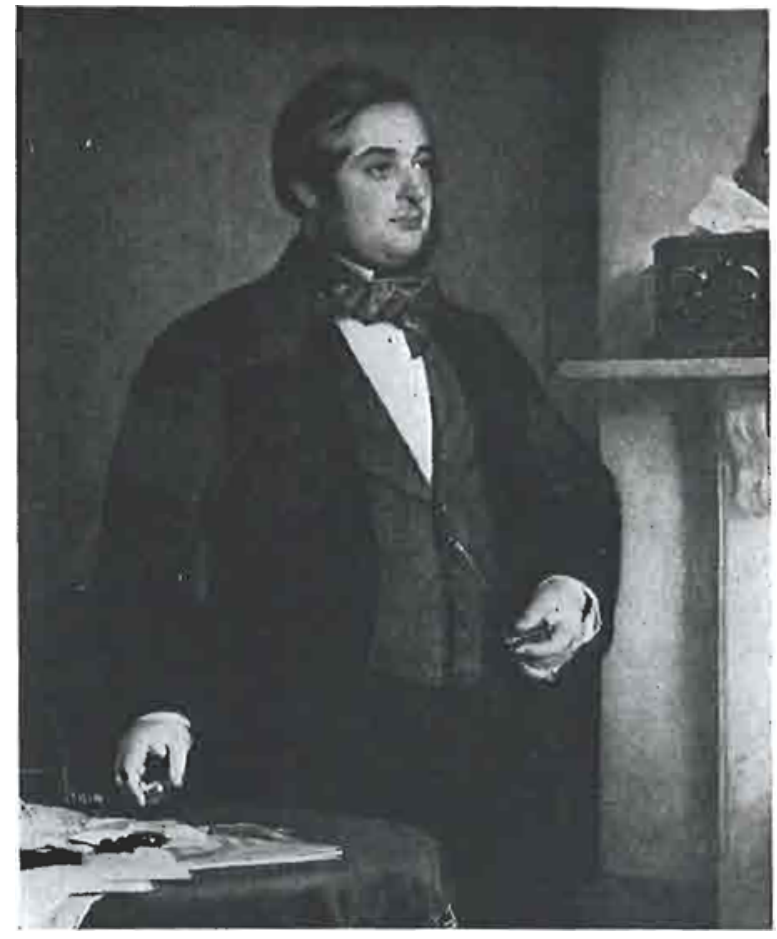

quantities of "metallic poisons" or impurities, but referred in passing to

"the different electro-chemical experiments I have made on the other metals and their compounds, together with the application of the facts to the processes of gilding, silvering, tinning, etc".

Davy promised to "give himself the pleasure of communicating this part of his research at no distant period", but there is no record of his ever having fulfilled the undertaking.

And now we come to Michael Faraday. As a young man of not quite 21, Faraday had built himself a Voltaic pile in the crude laboratory that he had established at the back of the shop belonging to Riebau, the book-binder to whom he was apprenticed. In a letter to his friend Benjamin Abbott, in July, 1812, he wrote

\footnotetext{
"Another phenomenon I observed was this : on separating the discs from each other, I found that some of the zinc discs had got a coating - a very superficial one in some parts-of metallic copper, and that some of the copper discs had a coating of oxide and zinc. In this case the metals must both have passed through the flannel disc holding the solution of muriate of soda, and they must have passed by each other. I think this circumstance well worth notice, for remember, no effect takes place without a cause. The deposition too, of the oxide of zinc in the flannel was curious, and will tend to illustrate the passage of the metals from one side to the other."
}

This intriguing phenomenon remained at the back of Faraday's mind for many years, but he was unable to give his full attention to it until in 1832 be began his famous series of investigations on electrochemical decomposition that, when published as his Seventh Series of Experimental Researches in December 1833,

\section{Warren de la Rue}

1815-1889

Eldest sou of Thomas de Ia Rue, founder of the famous firm of printers, Warren entered the business but at the same time carried out experiments on electrochemistry. In 1836 he observed the exaet reproduction of the polish and scratches on the copper cathode of a Daniell cell and so initiated the idea of securing smooth deposits instead of the dendritic growths so far obtained. Later he turned to astronomy, and achieved the rare distinction of becoming President of both the Chemical Soeicty and the Royal Astronomical Society.

(From a portrait by William Troutschold in the possession of the De La Rue Company)

put the whole subject of electrochemistry firmly upon its foundations.

These are too well known to need discussion here, except that one should in passing acknowledge our indebtedness for the nomenclature he established and which we use so freely today. Faraday turned for help to William Whewell of Trinity College, Cambridge, and a lengthy correspondence followed in which Whewell proposed anode and cathode instead of Voltode and Galvanode or eisode and exode among others suggested by Faraday, and followed these with anion and cation. Faraday himself had coined the words electrolysis and electrolyte.

\section{The Great Breakthrough}

The year 1836 was a significant one in the history of electrodeposition, for during its course the names of three men who in different ways greatly influenced its development were first brought into prominence.

In February of this year Professor J, F. Daniell, of King's College, London, described the first selfpolarising cell or constant battery. In the course of his experiments he found that metallic copper was deposited on his copper cylinders :

"The fresh-precipitated copper had a most beautiful appearance, being of a bright pink colour."

The great importance of Daniell's work was of course in providing at last a more reliable source of current for researchers in electrodeposition and in leading the way to the deposition of thin uniform coatings.

In the following June, George Richards Elkington of Birmingham filed his first patent for "An Improved Method of Gilding Copper, Brass and Other Metals or Alloys of Metals". Elkington referred to himself as "Gilt Toy Maker", a phrase that covered his activities, in partnership with his cousin Henry, as a manufacturer of military badges and buttons and other small articles such as snuff boxes and spectacle frames. In this context they were naturally interested in discovering improved means of gilding to replace the amalgamation method which had such injurious effects on the workmen. Here, however, we must 
leave Elkington for the moment, to return to the major part he played in gold plating a little later.

In September of 1836 Warren de la Rue, the eldest son of Thomas de la Rue, founder of the well-known firm of security and bank note printers that still bears the family name, was experimenting with Daniell's new source of current, and observed that

"the copper plate is also covered with a coating of metallic copper which is continually being deposited; and so perfect is the sheet of copper thus formed that, being stripped off, it has the polish and even a counterpart of every scratch of the plate on which it is deposited",

De la Rue's paper was published immediately in the Philosophical Magazine, but in his "Elements of Electrometallurgy", first published in 1840, Alfred Smee (for whom a special post was created at the Bank of England to enable him to pursue his researches on electrodeposition and electrotyping in particular) writes of de la Rue's observations:

"This paper appears to have attracted very little attention; and what appears still more singular, the author, although well qualified, from his scientific attainments, to have applied these facts, never thought of any practical benefit to which this experiment might lead.

Now de la Rue, then a young man of only 21 , was already active in the family printing business, and it is on record that "he earnestly applied his scientific knowledge to the improvement of various processes and the invention of many new ones." Unfortunately he did not follow up his experiments, although by 1840

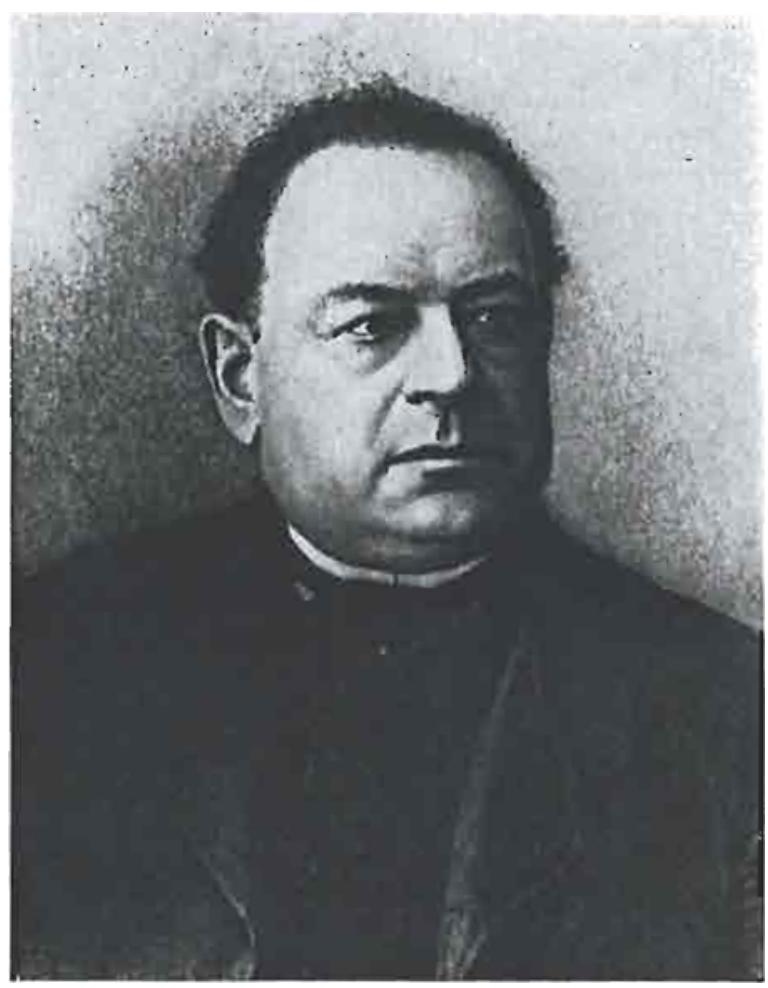

he was actively engaged in the preparation of electrotypes, and it is worth recording that in 1845 he published a paper "On the Structure of Electroprecipitated Metals", in the Philosophical Magazine in which for the first time the microscope was used to examine their cross-sections. He also recognised the effects of impoverishment of the cathode layer in electrodeposition.

\section{Jacobi and Electroforming}

It was in the February of the following year, 1837, that the famous Jacobi appeared on the scene. Moritz Hermann von Jacobi was born in Potsdam in Germany in 1801, but left in his early thirties, as did many other educated young men at that time, to make his career as an architect in Russia. Here he became known as Boris Semenovich Jacobi, and in 1834 he was appointed a professor at the Estonian University of Dorpat (nowadays known as Tartu) and it was here that he began his studies in electrochemistry by repeating the experiments already reported by Daniell in 1836 and again finding a deposit of copper. A month later, following up the observations of de la Rue, he employed as a cathode an engraved copper plate that had been used to print his visiting cards and obtained a clear impression of the engraved lines when the deposit was removed.

Later in this year Jacobi moved to St Petersburg to take charge of the Physics Laboratory of the Academy of Sciences. Here he continued his work in electrochemistry, and in October 1838 he reported to the Academy of Sciences on his process of "galvanoplastik". This was of course what we now call electroforming, and the first account of this practical application of electrochemistry was briefly noted in England in The Athenaeum of May 8th, 1839. A detailed account appeared a little later in the form of a letter from Jacobi to Faraday published in the Philosophical Magazine.

\section{Moritz Hermann vou Jacobi 1801-1874}

Following up the announcement of Daniell's primary cell and also the obscrvationg of de la Rue, Jacobi, in 1837 when a Professor in Estonia, also reproduced an engraved surface hy the electrodeposition of copper. Later, when at the Academy of Sciences in St Petersburg, he fully developed the process of electroforming. After the publication of the Elkington and Wright cyanide process in 1840 Jacobi played a major role in fostering the use of gold plating in Russia. So enthusiastic was he on his subject that he proposed to the Tsar the formation of a regiment of Sapeurs Galvanique! 
Almost immediately controversy erupted. Thomas Spencer, who had a thriving business as a carver and gilder in Liverpool, claimed that in the latter part of 1837 he had carried out experiments leading to the electroforming of medals and printing plates, while C. J. Jordan, a London printer, claimed that experiments he had made "about the commencement of last summer" resulted in impressions from engraved copper plates. Both had almost certainly benefited from de la Rue's original observations of 1836.

The ensuing arguments were to last for many years, but they cannot be detailed here; the names of Spencer and Jordan were to crop up again, however, in a much later controversy over the origins of successful gold plating. The immediate effect of these announcements was, however, a veritable explosion of interest and activity in electroforming on the part of both scientists and enthusiastic amateurs, the latter being able to buy simple apparatus and the necessary chemicals from a number of enterprising suppliers. Jacobi's monograph "Die Galvanoplastik", published in 1840, was at once translated into English by William Sturgeon, a lecturer and journalist specialising in electrical subjects, while Jacobi himself attended the meeting of the British Association for the Advancement of Science held in Glasgow in that year, at which some heated discussions and even demonstrations were apparently indulged in by the contesting parties.

But all these activities were confined to the production of heavy deposits of copper, and copper only, and there was still no sign of the electrodeposition of thinner films of gold or of any other metal as a means of protection or decoration.

\section{The Elkingtons and John Wright}

Jacobi was to play his part here too, but first we must return to the Elkingtons whom we left in the year 1836. Elkington's first patent did not involve electroplating, but rather an immersion or replacement process in which a thin layer of copper was dissolved by a boiling solution of gold oxide in potassium bicarbonate and replaced by an equally thin layer of gold. In the following year cousin Henry also filed two patents, but again these covered only immersion gilding. But in July 1838 one of Elkington's assistants, Oglethorpe Wakelin Barratt, together with the senior partner, filed a patent for coating copper and brass with zinc, the process involving the immersion of the metal to be coated in solution of zinc while in contact with a piece of metallic zinc or with zinc amalgam. Although no mention was made of a battery, this showed the first glimmer of the idea of a galvanic circuit.

All these four patents are of importance, however, as the fore-runners of British Patent 8447 , which was to play a major part not only in the rapid development of gold plating but in subsequent controversy and litigation. This was in the joint names of George Richards Elkington and Henry Elkington-now, incidentally, described as "gentlemen". Filed on March 25th, 1840, it covered "Improvements in Coating, Covering, or Plating certain Metals" and detailed a number of solutions of silver and gold compounds "in connection with the application of a galvanic current." The sources of current found to be most efficient and convenient were

"some forms of those used for philosophical purposes, and known by the name of constant or sustaining batteries. That which we prefer, and most frequently employ, consists of two concentric cylinders closed at the bottom, the outer one of which is of glazed and the inner one of unglazed and porous earthenware. The space between them forms a cell, into which is poured a solution of chloride of sodium or other exciting fluid; into this a cylinder of zinc is immersed, with a wire of copper soldered to it and made to bend over and dip into the inner vessel wherein is contained the solution of silver or gold".

The articles to be plated, after being carefully cleaned, were to be placed in the latter solution, attached to the copper wire, and the thickness of the deposit would depend upon the length of time they were allowed to remain in the solution and in contact with the wire of the battery.

At this period the Elkingtons employed another assistant, Alexander Parkes, later to become well known as the inventor of celluloid and also of phosphor-bronze. Parkes was engaged, together with the partners, in experimental work with the object of obtaining thicker and more coherent electrodeposits of gold and silver, and it is on record that he was paid $£ 200$ for his help in drafting the specification of the 1840 patent, in which O. W. Barratt also had a hand. The Elkingtons kept in touch with several leading chemists of the day, and were obviously most anxious to develop a more reliable plating technique.

Now during the six-month period between the filing of their patent and its completion date, September $25 \mathrm{th}$, a certain amount of excitement took place. In August the Elkingtons were introduced to John Wright, a local surgeon, by Charles Askin, who had abandoned his profession as a veterinary surgeon to enter into partnership with Brooke Evans in the manufacture of nickel-silver (the firm later becoming Henry Wiggin \& Co Limited). John Wright, who was born in 1808 in the Isle of Sheppey, began his medical career as an apprentice to a Dr Shearman of Rotherham, near Sheffield (a geographical circumstance that was to give rise to more controversy many years later), completed his training in Edinburgh, Paris and London and then settled in the Bordesley district of Birmingham in 1833. Like many other medical men of the time, he enjoyed experimenting with the new voltaic electricity. Undoubtedly, living 
It is remarkable, that our colouring matter, after it has united with the alkali, or with the lime, forms a menftruum, capable not only of diffolving metallic calces, but alfo of conftituting a triple falt, which is not decompofed by the aerial acid, as happens with the lixivium fanguinis and the precipitating liquor, when expofed to the free accefs of air. Iron is not the only metal which has the property of fixing the colouring matter ( $\$$ Ii. c), the fame quality belongs likewife to gold, filver, copper, and probably to feveral other metallic calces; for if after thefe calces have been precipitated, a fufficient quantity of precipitating liquor be added, in order to rediffolve them, the folution remains clear in the open air, and in this ftate the aerial acid does not precipitate the metallic calx.

as he did in the centre of the metal working industry, he became aware of the interest being taken in finding improved means of electrodepositing silver and gold. He would have been equally aware that solutions of many compounds of these metals had been tried and had yielded some kind of an electrodeposit, but that these were still most unsatisfactory for commercial purposes. He then happened to read a passage in Scheele's "Chemical Essays". In the course of Scheele's "Dissertation on Prussian Blue" included
In 1783 Carl Wilhelm Seheele, the famous Swedish chemist, published "A Dissertation on Prussian Blue". This paper, together with a number of his others, was translated into English by Thomas Beddoes and published in 1786. It was from reading this passage that John Wright conceived the idea of trying the complex cyanides as electrolytes for gold and silver plating.

The passage refers to the solubility in hydrocyanic acid (our colouring matter) of the cyanides (calces) of gold, silver and copper to give complex salts that arc not decomposed, as is an aqueous solution of potassium cyanide (lixivium sanguinis), on exposure to the carbon dioxide of the air (the aerial acid)

in this volume Wright noticed the paragraph reproduced here, describing the solubility of gold and silver cyanides in excess potassium cyanide, and he immediately tried these solutions as electrolytes. Success rewarded his experiments at once, coherent and firmly adherent deposits being obtained.

Wright showed his specimens to the Elkingtons, who were impressed by their appearance, but acting on the advice of Charles Askin, he firmly declined to disclose the details of his process until an agreement had been signed. A memorandum of agreement was therefore drawn up, dated September 1st, 1840, under which the new process was to be purchased by the Elkingtons for $£ 300$, with further substantial sums to follow if the process was later adopted and worked. Then, to quote from a letter written by $G . R$. Elkington:

"We found the process the same in principle as we were about to specify and we decided to embrace the variation, which consisted of a different solution, in our specification."
The signatures to the final agreement between the Elkingtons and Dr John Wright. This document details the terms on which Wright's discovery of the complex cyanides as successful gold plating electrolytes was ineorporated inte the Filkington's patent, they to pay Wright £300 upon the disclosure of his process, followed by a further $\mathbf{x} 500$ if the patent was granted and another $£ 700$ after a six-month trial period

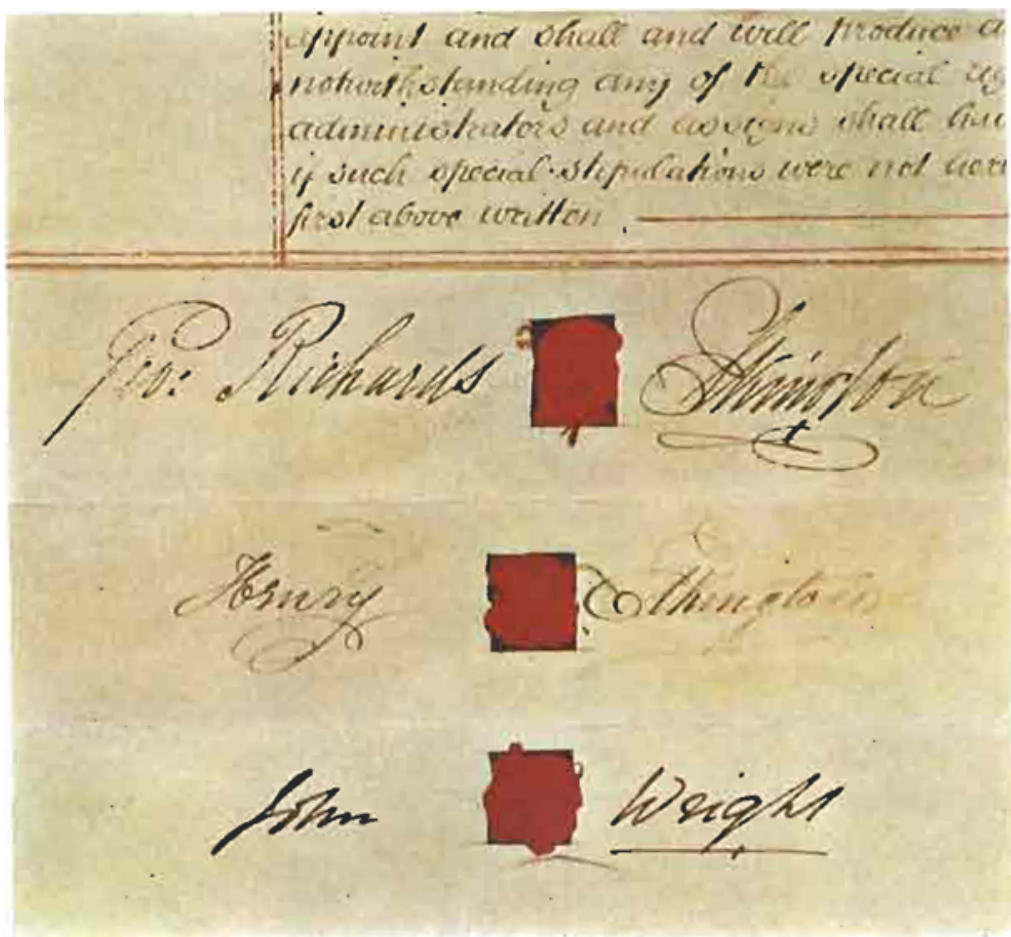


Thus with about three weeks to spare before the completion of their patent, the Elkingtons hastily had the cyanides written into the specification. A little later a more formal agreement, dated retrospectively to March 25th, 1840, the date of the filing of the patent, was drawn up. The three signatures to this agreement are illustrated here. John Wright's name thus never appeared in the patent literature, nor did he ever put his experimental work on record. Instead he seemed content to receive royalties from the Elkingtons and, conscious that he was not a robust individual, to secure substantial life payments for his wife. Unfortunately he did not live long to see his ideas successfully applied; he died in 1844 from paralysis caused by a fall from his carriage.

\section{The Great Controversy in France}

The Elkingtons pursued a policy of filing patent applications in a number of countries, and the corresponding French patent to No. 8447 was filed in France on September 29th and published on December 8th, 1840. But on December 19th a specification was filed in the French patent office by Henri-Catherine-Camille Ruolz, otherwise known as the Comte de Ruolz-Montchal, and was published on February 15th, 1841. Ruolz, during his twenties, had been a pupil of Rossini and had composed three operas, none of which had been successful. Having lost a great deal of money, he abandoned his musical career, taking up industrial chemistry instead, and very soon his attention was drawn to the dangers to the health of the workmen using the mercury process of gilding and to the very real need for a better process. The first patent by Ruolz concerned itself only with the problem of obtaining a gold coating-by immersion only-upon silver. During 1840 the well known scientist Professor A. A. de la Rive of Geneva had disclosed that, as long ago as 1828 , he had succeeded in gilding silver and platinum wires by employing them as negative electrodes in a solution of gold chloride, but that the deposits were not sufficiently adherent, and he had abandoned the process. Ruolz now claimed that this procedure, while satisfactory on copper and brass, was useless in attempting to gild silver, and his patent covered the prior deposition of a thin immersion coating of copper on the silver. During the following June, however, he filed an addition to his patent, published on October 11th, 1841, which covered both the use of the battery and "the employment, for the first time, of the compounds of cyanogen with gold and silver".

Ruolz, financially highly embarrassed, sold his rights in his patents to a Paris dyer, GuillaumeEdouard Chappée, but apparently acquired them back again. He also arranged with his numerous creditors that they should receive three-fifths of the

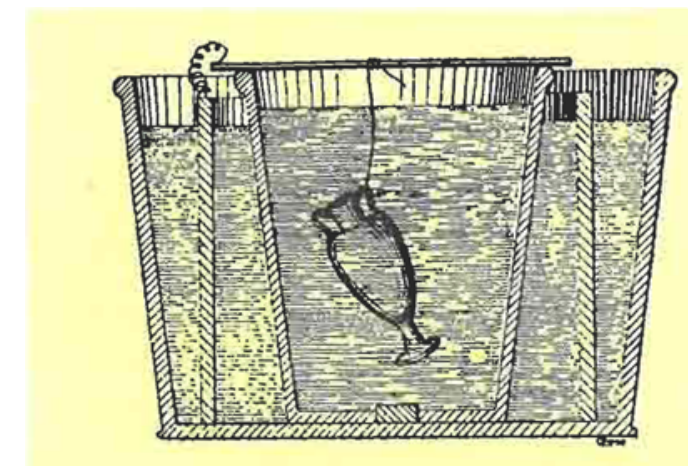

The first successful electroplating of a really coherent and adherent gold deposit was carried out by Dr John Wright at his house in the Bordesley district of Birmingham. An ordinary flowerpot containing the cyanide solution was placed in an outer vessel containing dilute sulphuric acid; the vase to be plated was connected by a wire to a sheet of zinc surrounding the porous cell and immersed in the dilute acid. Only a little later did the idea occur of separating the source of current from the plating bath, proposed independently by Thomas Mason of London and by Professor Jacobi of St Petersburg

profits from his inventions, he to retain two-fifths for his personal needs.

The great possibilities of Ruolz's patent were at once realised by Charles Christofle, the founder of a then small but enterprising jewellery manufacturing concern in Paris, and after seeing a demonstration in January 1842 he quickly secured an exclusive licence to operate the patent for gold and silver plating for which he paid 150,000 francs, while he also retained the services of Ruolz as a consulting chemist.

In the meantime, however, the Académie des Sciences, much concerned with any method that might replace mercury gilding, had appointed a commission of five scientists, led by the distinguished Jean Baptiste Dumas, to report on the methods proposed by de la Rive, the immersion methods covered by the earlier Elkington patents and the new claims of Ruolz for the alkaline cyanides. At once G. R. Elkington, who seems to have operated a formidable intelligence service, instructed his Paris lawyer to advise the commission of his patent for gold plating from a cyanide bath, a matter on which the commission expressed surprise at their ignorance. Demonstrations of the processes were carried out before the commission, and John Wright journeyed to Paris to play his part in these. The commission reported somewhat hastily by December 1841, leaning rather heavily towards their own national, Ruolz, and six months later they awarded prizes of 3,000 francs to de la Rive for the application of the pile for the gilding of metals, 6,000 francs to Elkington for his galvanic method of gilding, and also 6,000 
francs to Ruolz for "the industrial application of a great number of means of gilding and silvering".

Charles Christofle clearly saw the merits of the Elkington and Wright process, and in May of 1842 came to an agreement with them to take a licence under their patent, for which he paid the very considerable sum of 500,000 francs. Christofle thus had the rights to both the Ruolz and the Elkington patents, but his troubles were by no means over. There were numerous cases of infringement to be fought, some of the defendants claiming that both Brugnatelli and de la Rive had successfully carried out gold plating, but the courts held that true invention lay with Elkington and Ruolz in covering objects to be gilt with an adhesive and continuous layer of gold acceptable in commerce, and without attacking the surface to be plated, as had de la Rive's process.

Then in 1845 Ruolz severed his connection with Christofle and began to pursue something of a vendetta against him and Elkington, although he had in fact benefited financially from the arrangement to a very considerable extent. The unsavoury and lengthy campaign, stoutly rebutted by Christofle (who alleged among other items that Ruolz had had prior access to Elkington's French patent and had simply added in the cyanides in his own patent of addition) went on for some five years and produced a vast amount of letters, affidavits, agreements and other legal documents, mostly to the discredit of Ruolz. Finally in 1851, Christofle published the whole of the documents in a book running to well over 400 pages (and carrying an approving foreword from Elkington) entitled "Histoire de la Dorure et de l'Argenture Electro-chimique". By now, he was well established as the leading gold and silver plater in France.

\section{Further Progress with the Elkingtons}

At home in Birmingham the Elkingtons too had their problems. Opposition and scepticism from the trade, failure to secure the sale of licences to work the process, the necessity to acquire for themselves allied patents taken out by others including members of their own staff, infringement of their patentsall these worries beset them in full as well as the problems of bringing the process nearer to perfection

\section{Charles Christofle $1805-1863$}

Founder of the well-known Paris firm of goldsmiths, silversmiths and cutlery manufacturers that still bears his name, Christofle had the foresight to realise the great importance of the patents filed by Ruolz and Elkington and he became a licensee of both. Despite an extraordinary number of legal actions he had to fight, and even more violent debate lasting for over five years, he established a highly successful business in gold and silver plating in France.

(From a portrait in the possession of L'Orfeveric Christofle :Paris) and the need for more capital in the business. But a stout partner was at hand. In 1840 George Elkington had purchased a house from Josiah Mason, and on the acquaintance developing, Mason entered into the partnership and in March 1842 the firm became Elkington, Mason and Co. The new partner was a self-taught man of great character and business ability who had made a considerable success as a manufacturer of split-rings and steel pens. Although his new venture was regarded with alarm by his friends, Mason saw the important future awaiting the plating of both gold and silver, and threw his energies into the business side of the firm and into the building and equipping of a new factory employing 300 workers.

Many years later, in the course of replying to an address on his founding of the Mason Science College, the forerunner of the University of Birmingham, Mason, then Sir Josiah, observed that

"accident brought me in close relations with my late valued friend and partner $\mathrm{Mr}$ G. R. Elkington who was then applying the great discovery of electrodeposition, and through my association with him in this undertaking I may claim a share in the creation of a form of scientific industry which has so largely enriched the town of Birmingham and increased its fame throughout the world".

The Elkingtons, as well as eagerly acquiring rights in patents filed by others, now acquired a useful working team of assistants. Oglethorpe Wakelin Barratt and Alexander Parkes have already been mentioned. In 1842 they also took on to their staff James Napier, a Glasgow-born chemist who had earlier worked in dyeing but had carried out experiments in electrotyping for the publisher J. J. Griffin.

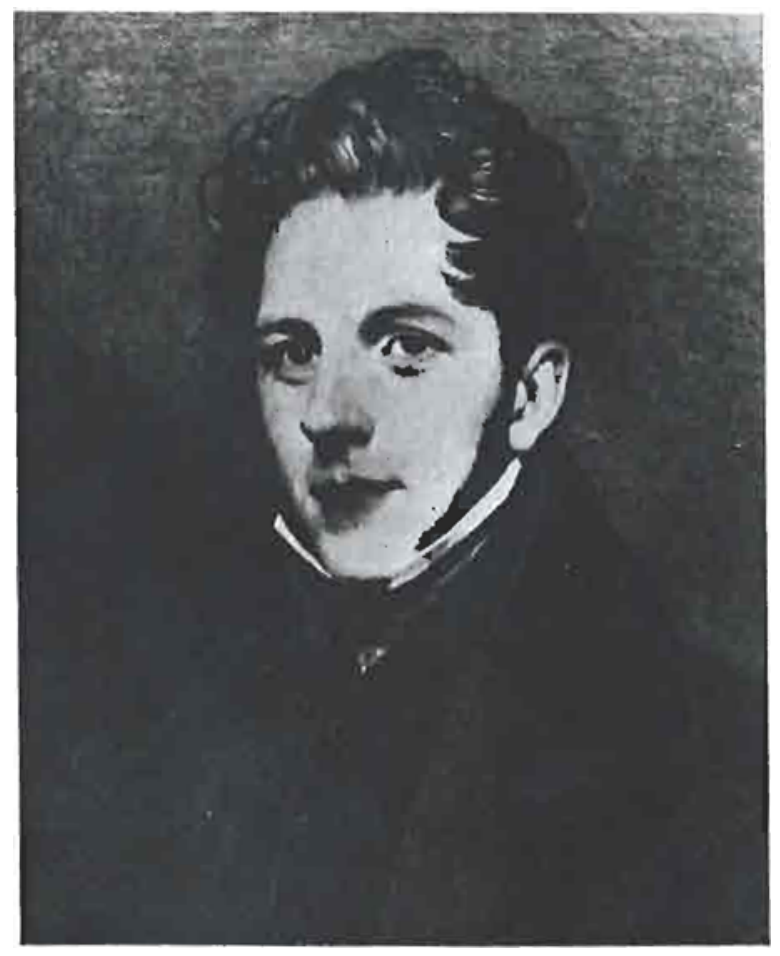




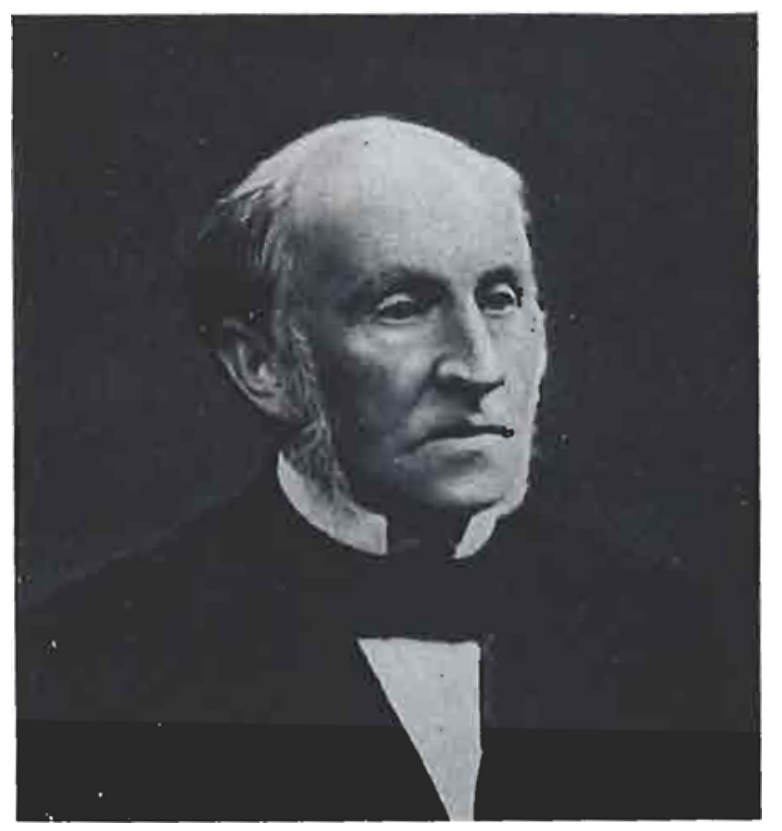

Alexander Parkes

$1813-1890$

One of the Elkington's most stalwart supporters, Parkes joined the company in charge of the Casting Department but quickly interested himself in electroplating and in eleetroforming. He took part in the early experiments on the cyanide electrolytes with Joln Wright and in 1841 sccured his first patent on "Producing Works of Art in Metals by Electric Deposits"

Napier was soon given charge of the electroplating department in the London works that they had opened, and in 1844, together with another associate Charles Glassford, published a very comprehensive paper on the chemistry of the gold and silver cyanides in the Philosophical Magazine. In 1852 his "Manual of Electrometallurgy" appeared. Another employee was William Millward, the originator of the use of carbon bisulphide as a brightener in silver plating baths.

In June 1842 Dr Henry Beaumont Leeson of Greenwich filed a massive patent, No. 9374, published in the following March, which included the

Two eleetroformed and gold plated vases produced by Alexander Parkes and now in the possession of the Science Museum in Loudon. They hear the Elkington's date mark for 1845 concept of agitating either the articles to be plated or the plating solution in order to obtain smooth deposits at higher current densities, the use of mercury "quicking", and some hundreds of compounds of silver, gold and the platinum metals as electrolytes. Leeson was an assistant lecturer in chemistry and forensic medicine at St Thomas' Hospital in London, later becoming a senior physician and dean, but he evidently gave a great deal of time to his electrodeposition studies. This patent, as usual, was drawn to the attention of the Elkingtons, and by the August of 1843 they had acquired exclusive rights therein for £300.

Another patent problem was also giving them anxiety at the same time. This, No. 9431, was filed in August 1842 by John Stephen Woolrich, the young son of John Woolrich who was lecturer in chemistry at the school of medicine and surgery in Birmingham and who is reliably reported-in George Shaw's "Manual of Electrometallurgy" published in 1842-to have

"succeeded in gilding an article by voltaic precipitation
from the ammonical solution of gold before the published
experiments of Mr Jordan and Mr Spencer appeared".

Probably young Woolrich was brought up in an electrochemical atmosphere, but in any case the

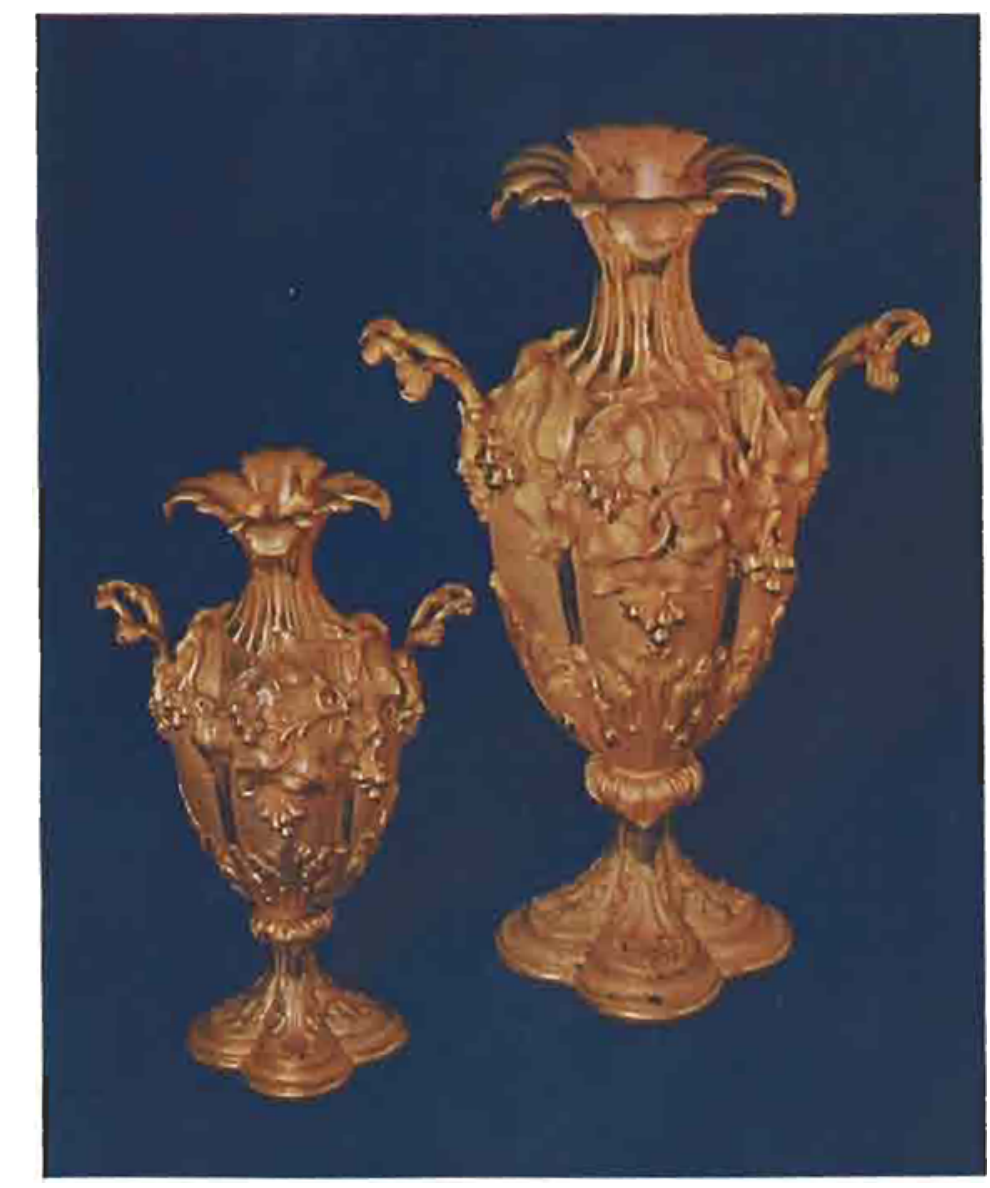


claims of his patent were twofold, first the use of a magneto-electric machine instead of batteries for electroplating, and secondly (and of more concern to the Elkingtons) the use of the sulphites of gold and silver-a form of electrolyte even nowadays causing a certain amount of debate! Woolrich junior first asked the Elkingtons for the astonishing sum of $£ 15,000$ for his patent, an offer they naturally declined. Counsel's opinion was sought, interestingly enough from William Grove, the inventor of the battery who later turned to the law, and a great deal of acrimonious correspondence followed, including letters from Charles Askin who had now befriended Woolrich. The latter disposed of his patents to Brooke Evans (the other co-founder of Henry Wiggin) who licensed three other plating firms before Elkingtons, in May 1845, also came to an agreement to pay $£ 100$ at once and $£ 400$ per annum for the life of the patent. Curiously, Woolrich himself was also licensed back under his own patent to operate in the small business he had set up in Great Charles Street, Birmingham, the Magneto-Plating and Gilding Works, but unfortunately he died in 1850 at the early age of 29 .

\section{Progress in Germany and Russia}

So far we have been recounting the history of gold plating largely in England and France. What was happening in the other countries of Europe? One rather interesting development that was unfortunately not destined to come to fruition took place in the fortress of Magdeburg in Prussia, where in 1841 Werner Siemens, then a young artillery officer, had been confined to barracks for taking part in a duel. Deeply interested in Jacobi's published work on copper electrodeposition, Siemens had smuggled into his cell enough apparatus and chemicals to pursue experiments in electrolysis, and working by analogy with the use of sodium thiosulphate in the dissolution of silver salts in Daguerre's new process of photography he tried the same compound in gold plating, using a louis d'or as an anode, and met with instant success. He then sold his process to a Magdeburg jeweller and also commissioned his brother William (afterwards Sir William) to journey to England and to endeavour to market his patent. William duly visited the Elkingtons in Birmingham in 1842 and after some discussion sold the patent for $£ 1,500$, a transaction that Werner later referred to as "in our then circumstances a colossal sum which put an end for some time to our financial difficulties".

Another leading exponent of gold plating in Germany at this time was Professor Franz Carl Leo Elsner of the Royal Technical Institute in Berlin who in 1843 examined and reproduced the methods put forward by Ruolz but endeavoured at some length to establish a process that did not involve the cyanides. None the less the use of cyanide baths began to spread slowly and plating shops were set up in Berlin, Stuttgart and other major cities, although the further development of electroplating had to wait another thirty years for the more general industrial development of Germany after its unification in 1871 .

It was in Russia, however, that the most exciting developments in gold plating took place. Jacobi, now established as a scientist and regarded with favour by Tsar Nicholas I, was naturally in a position to encourage the further exploitation of electrodeposition in any form, and in 1843 he reported to the St Petersburg Academy of Sciences on a method put forward by a local dentist named Briant. Jacobi had himself repeated the methods of de la Rive, Ruolz and Elkington as set out in the Dumas report to the Académie des Sciences in Paris, and he was ready enough to acknowledge that

"this important and interesting aspect of clectroplating technique for which we have to thank Mr Elkington now occupies an important place in technical arts and crafts".

Briant's variation consisted chiefly of using the ferrocyanides instead of the more readily decomposable potassium gold cyanide patented by Elkington, and Jacobi expressed the opinion that this process was more suitable for large-scale production. Aleksie Fedorovich Grekov, who began as a photographer and camera maker but turned to electroplating, also used ferrocyanides, adding a little copper sulphate to give a redder colour to the deposit in order to compete more favourably with the appearance of mercury gilding. He also deposited gold alloys containing silver.

The industrial development of gold plating really began, however, with the opening in 1844 of a large plant for electroforming and electroplating in $\mathrm{St}$ Petersburg by Duke Maximilian von Leuchtenberg, a German nobleman who had married the eldest daughter of the Tsar and had settled in Russia. Leuchtenberg had the cooperation of Jacobi as well as the financial support of the Tsar, and a great deal of electroforming of copper statuary and bas-reliefs was carried out as well as silver and gold plating from cyanide solutions.

But the most astonishing achievement in this plant was the gold plating of the bronze domes of the new Church of the Redeemer, then being built in Moscow. All the many domes of the Moscow churches had hitherto been gilt either with gold leaf or by a hot dipping method but electroplating had now advanced sufficiently for it to be used on this large scale. The five domes were first assembled in the plating shop, each sheet being numbered, and then dismantled. The gold plating was carried out in three large wooden vats, each containing over 
The first example of gold plating to specification was almost certainly the gilding of the five domes of the Chureh of the Redemer in Moscow. Built to commemorate the defeat of Napoleon, many years. In 1854 the domes-the largest 100 feet in diameter-were gold plated in the plant of Duke Maximilian von Leuchtcuberg in St Petersburg, the amount of gold deposited being tested by a special commission which checked two out of every 100 sheets plated. The specification called for 28.44 grams of gold per square metre, with a tolerance of 20 per cent, and if the samples did not meet these requirements the whole batch was rejected. The total weight of gold deposited was slightly less than 500 kilograms. Unfortunately the ehurch was demolisherl after the revolution and its site is now occupied by the work began in 1839 and continued for giant Moskva swimming pool

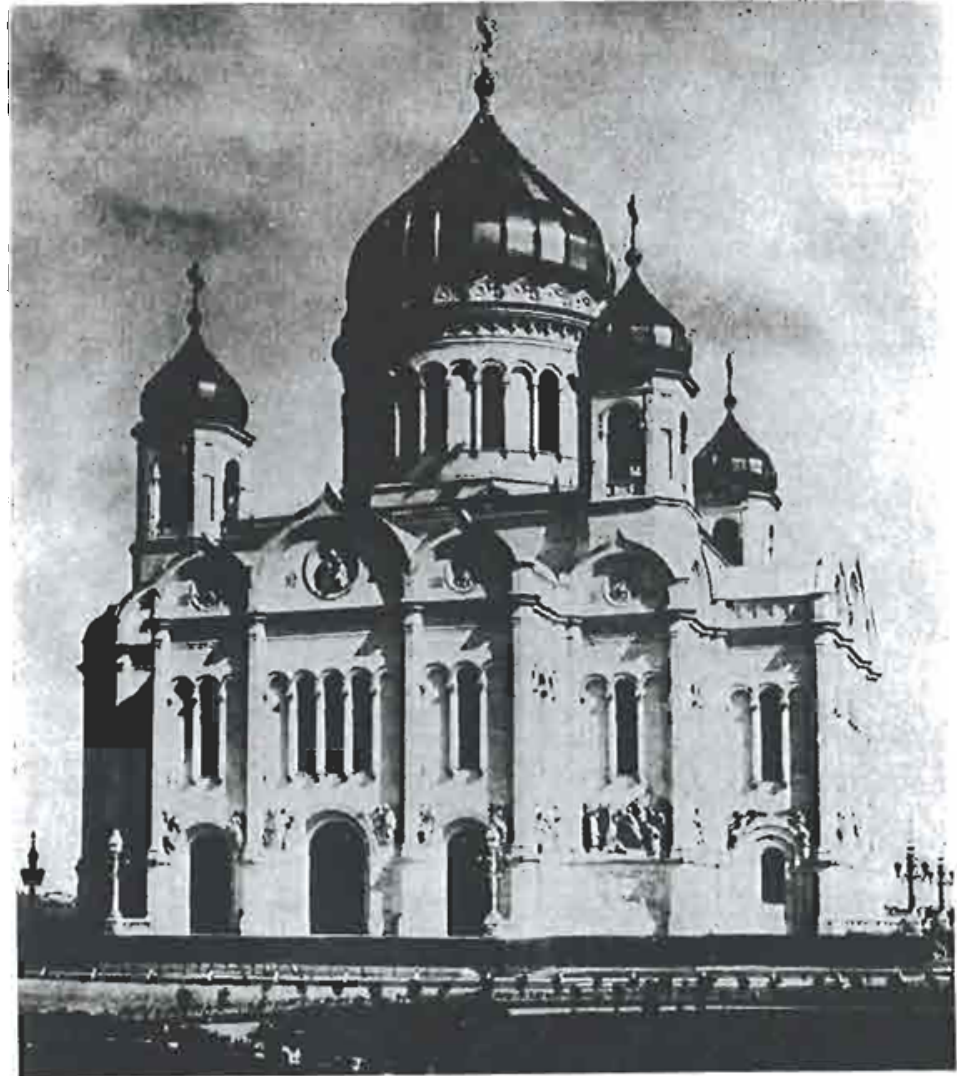

5,000 litres of cyanide solution, the sheets being slowly agitated by hand.

\section{The Later Controversies}

Returning now to England, where the Elkingtons had acquired a dominating position in silver and gold plating-in 1851 they are recorded as employing 500 workpeople-and were also very active in the electroforming of reproductions of works of art, we find still more disputes and controversies. In 1863 one Henry Dirks, a civil engineer, published a hundred-page pamphlet with the title "A Contribution towards a History of Electrometallurgy establishing the Origin of the Art". This, dedicated to Faraday, extolled the merits and claims of C. J. Jordan as the "inventor" of electrometallurgy in June 1839 !

George Elkington died in September 1865 (cousin Henry had died in 1852) but even in death he was not free from controversy. On December 5th The Times published a short obituary notice reproduced from the Fournal of the Royal Society of Arts but gave it the heading "The Inventor of Electro-Plate". This at once drew letters to the Editor from Thomas Spencer who claimed that

"early in 1838 he had succeeded in plating articles thickly with the precious metals"

and also a disclaimer from the Editor of the fournal of the Royal Society of Arts about the heading of the obituary notice, adding the comment that as regards the invention of electroplating at least four persons, Spencer, Jacobi, Jordan and Wright, had some claim. This prompted a further letter from Spencer which referred to "a Mr Wright of whom, I assure you, I now hear for the first time".

The last round of this correspondence came, however, from John Wright's brother William, who wrote on December 12th

"I claim for my brother, the late Mr John Wright, surgeon of Birmingham, the honour of being the inventor of that process. I have never heard of Mr Spencer or any one else disputing the patent with Mr Elkington or yet claiming any royalty."

Even further debates and controversy occurred and recurred quite some years later, particularly in the Sheffield newspapers of 1881, 1887, 1890 and again as late as 1903-04. These arose from the erroneous conviction that Elkington's collaborator Dr Wrightthe Christian name had numerous versions-was associated with Sheffield, and that the origins of silver and gold plating really belonged to that city. (Even the great Dr John Percy got it wrong in his "Metallurgy of Silver and Gold", published in 1880, where he referred to "Mr Alexander Wright, surgeon of Birmingham). This firmly held view was finally refuted, however, by the researches of $\mathrm{R}$. E. Leader into the Elkington archives which he painstakingly Victoria and Albert Museum in London. collated in 1913 and which are now preserved in the 